\title{
Bacterial ecology and rheological parameters of multigrain gluten-free sourdoughs
}

\author{
J.O. Adepehin ${ }^{\mathrm{a}, *}$, V.N. Enujiugha ${ }^{\mathrm{a}}$, A.A. Badejo ${ }^{\mathrm{a}}$, G.M. Young ${ }^{\mathrm{b}}$, D.A. Odeny ${ }^{\mathrm{c}}$, F. Wu $^{\mathrm{d}}$ \\ ${ }^{\text {a }}$ Department of Food Science and Technology, Federal University of Technology, Akure, Nigeria \\ ${ }^{\mathrm{b}}$ Department of Food Science and Technology, University of California, Davis, USA \\ ${ }^{\mathrm{c}}$ International Crops Research Institute for the Semi-Arid Tropics (ICRISAT), Nairobi, Kenya \\ ${ }^{\mathrm{d}}$ College of Food Science and Technology, Huazhong Agricultural University, China
}

A R T I C L E I N F O

\section{Keywords:}

Dough

Underutilised cereals

Fermentation

Microbial diversity

Gene sequence

\begin{abstract}
A B S T R A C T
The microbial diversity and pasting properties of three sourdoughs produced from composite gluten-free flours were investigated using 16S rRNA gene clone libraries and the Rapid Viscoanalyser. Finger millet-pearl millet (FP), Pearl millet-sorghum (PS) and Finger millet-sorghum (FS) sourdoughs were produced. Eleven aerobic bacteria and twelve lactic acid bacteria (LAB) were randomly selected from the sourdoughs. Presumptive Bacillus subtilis and Pediococcus spp. were identified in all the sourdoughs after $48 \mathrm{~h}$ of fermentation, while yeast was not detected in any of the products. The $\mathrm{LAB}$ population and $\mathrm{pH}$ ranged from $\log 7.70 \mathrm{CFU} \mathrm{g}^{-1}$ to $\log 10.52 \mathrm{CFU} \mathrm{g}^{-1}$ and 3.8 to 4.2 respectively. The findings showed that well-developed sourdough could be produced from these composite flours by spontaneous fermentation. Significant differences were observed in the pasting properties of all the sourdoughs. Decline in the tendency to retrograde occurred in all sourdoughs, thereby justifying the lower staling rate of final products. This study enhanced the corpus of existing knowledge on the microbial diversity of gluten-free sourdough and provided a basis for the possible application of Pediococcus spp. and Weisella spp. as a starter culture(s) in fermented products.
\end{abstract}

\section{Introduction}

Fermented food possesses an ecosystem that comprises lactic acid bacteria (LAB), acetic acid bacteria and other Gram positive/negative and/or fungi that contribute to its several beneficial characteristics, such as prolonged shelf-life, improved texture and organoleptic properties (Wood, 1998). Cheese, yoghurt and sourdough are some of the examples of myriads of fermented food commonly consumed. Sourdough is a mixture of milled cereal and water that is spontaneously fermented (Gobbetti, 1998; Vrancken, Rimaux, Weckx, Leroy, \& De Vuyst, 2011) by the action of LAB and yeasts leading to improved dough structure, aroma, palatability, nutritional value and prolonged shelf-life (Moroni, Dal Bello, \& Arendt, 2009). Previous studies have affirmed that the positive effects of LAB on dough include the release of small peptides and free amino acids, which are essential for $\mathrm{pH}$ reduction, rapid growth of microorganisms, precursors for flavour development (Rollan, De Angelis, Gobbetti, \& De Valdez, 2005), larger and evenly distributed gas cells, higher loaf volume (Edema, Emmambux, \& Taylor, 2013), accumulation of bioactive peptides (Hu et al., 2011) and metabolite production (Galle, 2013).

Specifically, it was reported that the presence of Leuconostoc species had improved the visco-elastic properties of sour maize dough (Edema, 2010). According to Salovaara (2004), some common LAB species found in sourdoughs include Lactobacillus acidophilus, Lactobacillus farciminis, Lactobacillus delbrueckii (obligate homofermentative), Lactobacillus casei, Lactobacillus plantarum, Lactobacillus rhamnosus (facultative heterofermentative), Lactobacillus brevis, Lactobacillus sanfransicencis and Lactobacillus fermentum (obligate heterofermentative). Studies have shown that the dominant microbial species in sourdough is influenced by temperature and type of flour (Vrancken et al., 2011; Ercolini et al., 2013; Harth, Van Kerrebroeck, \& De Vuyst, 2016; Ogunsakin et al., 2017). Hence, it becomes imperative in product development to scrutinize the flour to be used, so as to ascertain the microbial community present in it. This will not only ensure the safety of targeted consumers, but also help food scientists to develop healthy starter cultures that can be of immense benefit to the food production sector.

Pearl millet (Pennietum glaucum), finger millet (Eleusine coracana) and sorghum (Sorghum bicolor) are gluten-free cereals known to be rich sources of energy and used in the production of fermented foods (Akinola, Badejo, Osundahunsi, \& Edema, 2017; Nazni \& Shalini, 2010). In addition to these benefits, flour-blends have the characteristic advantage of synergistically combining the strengths of individual

\footnotetext{
* Corresponding author.

E-mail address: joadepehin@gmail.com (J.O. Adepehin).
} 
grains, thereby making up for possible weaknesses of the individual flour. Three multigrain flours, each containing two of the listed cereals in equal proportion, were screened for microbial diversity and pasting properties. This work is part of a large-scale and ongoing research aimed at producing bread from underutilized gluten-free African cereals using sourdough technology. As with the development of new food products, several components that could affect the resultant product's nutritional value, acceptability and organoleptic quality must be ascertained. The key objective of this research was to identify predominant fermenting organisms in the dough, which could be utilized for the development of a starter culture, and to understand the rheological parameters of the fermented multigrain sourdough.

\section{Materials and methods}

\subsection{Sample collection}

Flours made up of Finger millet (Eleusine coracana) of the KNE 1149 variety (F), Pearl millet (Pennisetum glaucum) of the ICMV 221-White variety (P) and Sorghum (Sorghum bicolor) of the KARI MTAMA 1 variety (S) were used. These grains were sourced from the International Crops Research Institute on Semi-Arid Tropics (ICRISAT) in Nairobi, Kenya. The grains were cleaned, milled through a knife mill and sieved to a particle size of $\leq 0.2 \mathrm{~mm}$. The flours were stored in labelled airtight containers for further analyses. The proximate composition (dry matter basis) of the grains was obtained using the AOAC (2005) method. The respective values for F, P and S are as follows; protein $(\mathrm{N} \times$ 6.25),18.26 $\pm 0.88 \%, \quad 18.58 \pm 0.02 \%$ and $9.84 \pm 0.91 \%$, fat; $8.90 \pm 0.01 \%, \quad 9.65 \pm 0.14 \%$ and $6.94 \pm 0.42 \%$, crude fibre; $2.22 \pm 0.17 \%, \quad 1.31 \pm 0.12 \%$ and $1.62 \pm 0.09 \%$, ash; $2.12 \pm 0.08 \%, 1.58 \pm 0.11 \%$ and $1.34 \pm 0.24 \%$, total carbohydrate; $68.49 \pm 1.13 \%, 68.88 \pm 0.07 \%$ and $80.26 \pm 1.48 \%$.

\subsection{Sourdough preparation}

Preparation of sourdough was done using the Type I sourdough technique, which does not require the use of starter culture(s). Three composite flours, namely finger millet-pearl millet (FP), pearl milletsorghum (PS) and finger millet-sorghum (FS), were mixed in equal proportion (50:50) to allow for equal expression of its unique properties, whereby none of the sourdough predominates the other quantitatively. The sourdough from of each of the developed blends were than produced, as previously described by Edema et al. (2013), with slight modifications. The flour-to-water ratio was 1:2 due to the dough's consistency. The flour and tap water were thoroughly mixed and allowed to ferment naturally at room temperature $\left(27^{\circ} \mathrm{C}\right)$ for $48 \mathrm{~h}$. Preparations were carried out in triplicate.

\section{3. $p H$ determination, enumeration and isolation of cultivable bacteria and yeast}

Prepared samples were analysed every $12 \mathrm{~h}$ for a total duration of $48 \mathrm{~h}$ so that each sample was analysed four times within the stated period. The $\mathrm{pH}$ was determined using a Model pHs-25 pH meter, and all analyses were carried out in triplicates. Ten grams of each sample was homogenized with $90 \mathrm{ml}$ of sterile $0.85 \%$ (wt./vol.) $\mathrm{NaCl}$ solution. Viable bacteria and lactic acid bacteria were enumerated at $37{ }^{\circ} \mathrm{C}$ for $24 \mathrm{~h}$ under aerobic conditions and $37^{\circ} \mathrm{C}$ for $48 \mathrm{~h}$ under anaerobic conditions, respectively. The media used for the former was Nutrient agar (NA) with cycloheximide $\left(0.1 \mathrm{~g} \mathrm{~L}^{-1}\right)$, while the latter used the de Mann Rogosa and Sharpe (MRS) agar. Rose Bengal Chloramphenicol (RBC) agar was used for enumerating yeasts at $30^{\circ} \mathrm{C}$ for $72 \mathrm{~h}$ under aerobic conditions. Culture dependent approaches were used for investigating the sourdough microbiota. At least 11 colonies of presumptive bacteria were randomly selected from plates containing the three highest sample dilutions with distinct colonies. The isolates were re-streaked on Nutrient agar with cycloheximide $\left(0.1 \mathrm{~g} \mathrm{~L}^{-1}\right)$ and cultivated in Nutrient broth at $37^{\circ} \mathrm{C}$ for $24 \mathrm{~h}$. About three randomly selected colonies of Gram positive, catalase negative rod and coccus from plates containing the three highest sample dilutions with distinct colonies were re-streaked and sub-cultured on MRS broth at $37^{\circ} \mathrm{C}$ for $72 \mathrm{~h}$. Stock cultures were stored at $-20^{\circ} \mathrm{C}$ in $10 \%$ (vol/vol) glycerol.

\subsection{Genotypic identification of bacteria}

The Genomic DNA of bacteria was extracted using the Wizard Genomic DNA purification Kit (Promega Corporation) according to manufacturers' instruction. For identification of presumptive bacteria and lactic acid bacteria, two primer pairs, namely 27F (5'-AGAGTTTG ATCMTGGCTCAG-3') and 1492R (5'-GGTTACCTTGTTACGACTT-3'), were used for amplifying the 16S rRNA genes. Electrophoresis was carried out on $1.5 \%$ agarose gel, while the amplicon was purified using Wizard SV Gel and PCR Clean Up System (Promega Corporation; USA). The amplicon was then sequenced using the Dye Terminator. Sequence alignments were carried out using the multiple-sequence alignment method called ClustalW2 (http://www.ebi.ac.uk/Tools/msa/clustalw2) and the sequence was identified by a BLAST search in the GenBank (http://www.ncbi.nlm.nih.gov/GenBank/).

\subsection{Pasting properties}

Pasting properties were determined using the Rapid Viscoanalyzer (RVA Super 4, Australia), as previously described by Akinola et al. (2017). The procedure was carried out according to the operational manual. Prior to loading the sample in to the RVA, $2 \mathrm{~g}$ of flour each were dried in an oven at $105^{\circ} \mathrm{C}$ to obtain a constant weight. A programmed heating and cooling cycle was used at a constant shear rate, where the sample was held at $50^{\circ} \mathrm{C}$ for $1 \mathrm{~min}$, heated from $50^{\circ} \mathrm{C}$ to $95^{\circ} \mathrm{C}$ at $6{ }^{\circ} \mathrm{C} / \mathrm{min}$, held at $95^{\circ} \mathrm{C}$ for $5 \mathrm{~min}$, cooled to $50^{\circ} \mathrm{C}$ at $6{ }^{\circ} \mathrm{C} / \mathrm{min}$ and held at $50{ }^{\circ} \mathrm{C}$ for $5 \mathrm{~min}$.

\subsection{Statistical analyses}

Data were subjected to one-way Analysis of Variance (ANOVA), while Duncan's Multiple range test was used to separate the mean at a significance level of $\mathrm{P}<0.05$. All data were determined in triplicate and analyses were performed using the Statistical Package for Social Sciences (SPSS) 16.0 version software.

\section{Results and discussion}

\subsection{Microbial population and acidification dynamics during sourdough fermentation}

Colony counts on nutrient agar at the beginning of the fermentation revealed the presence of bacteria in all the sourdoughs produced (Fig. 1). A drastic increase in bacterial growth $(P<0.05)$ was observed in all sourdoughs within the $12 \mathrm{~h}$ fermentation period. The significant difference in bacterial population between the $0-12 \mathrm{~h}$ of fermentation is indicative of a favourable environmental condition. The peak cell density of FS was attained at $12 \mathrm{~h}$ fermentation, while that of FP and PS were attained at $24 \mathrm{~h}$ fermentation. The sourdoughs generally recorded cell densities within the range of $\log 9.60$ (PS) and log 11.48 (FS) CFU $\mathrm{g}^{-1}$. A decline in the bacterial count was observed in the sourdoughs following the attainment of maximum cell densities. This waning in bacterial count is attributed to the corresponding increase in the dough's acidity (Fig. 3). Corsetti and Settanni (2007) and Weckx et al. (2010) had independently stated that some microbes die off with an increase in fermentation time, owing to its inability to survive in acidic medium.

Final bacterial loads in the sourdoughs at $48 \mathrm{~h}$ fermentation were slightly different, having values of $\log 7.95, \log 8.30$ and $\log$ 


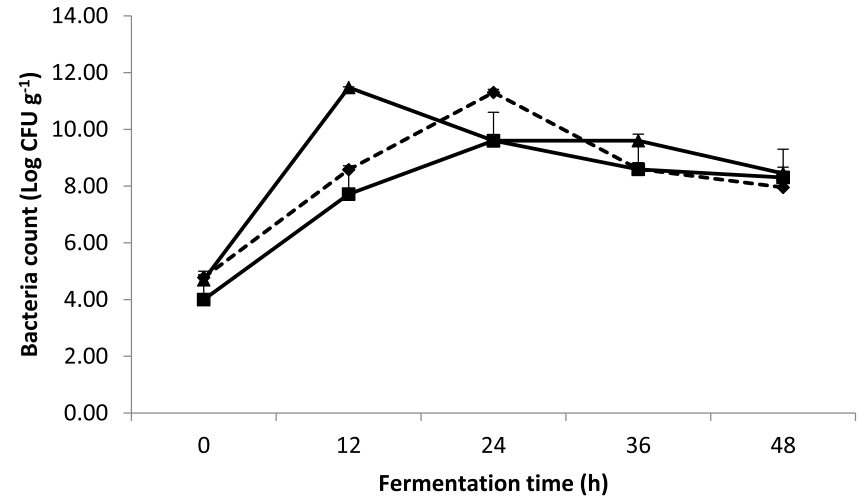

Fig. 1. Bivariate plot showing bacteria population dynamics ( $\log \mathrm{CFU} \mathrm{g}^{-1}$ ) with fermentation time in the three sourdoughs produced from composite flours. - - . Finger millet-pearl millet blend,_— Pearl millet-sorghum blend, Finger millet-sorghum blend. Plotted values are mean of triplicate readings.

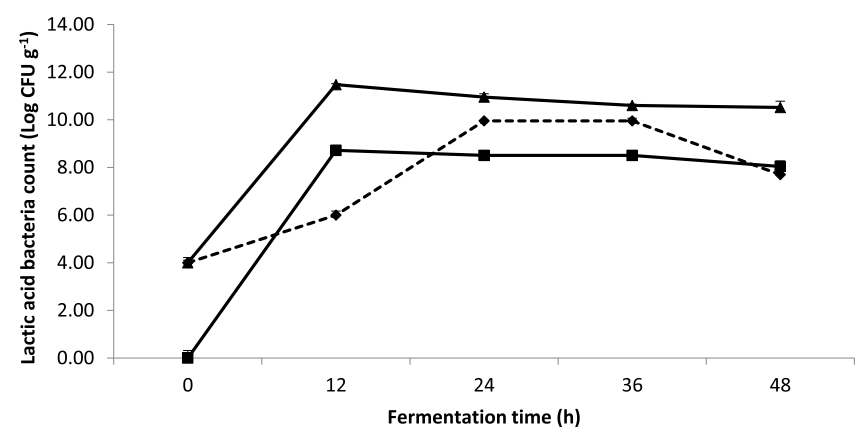

Fig. 2. Bivariate plot showing lactic acid bacteria population dynamics (Log CFU $\mathrm{g}^{-1}$ ) with fermentation time in the produced sourdoughs. -millet-pearl millet blend, _ـ Pearl millet-sorghum blend, _ـ F Finger millet-sorghum blend. Plotted values are mean of triplicate readings.

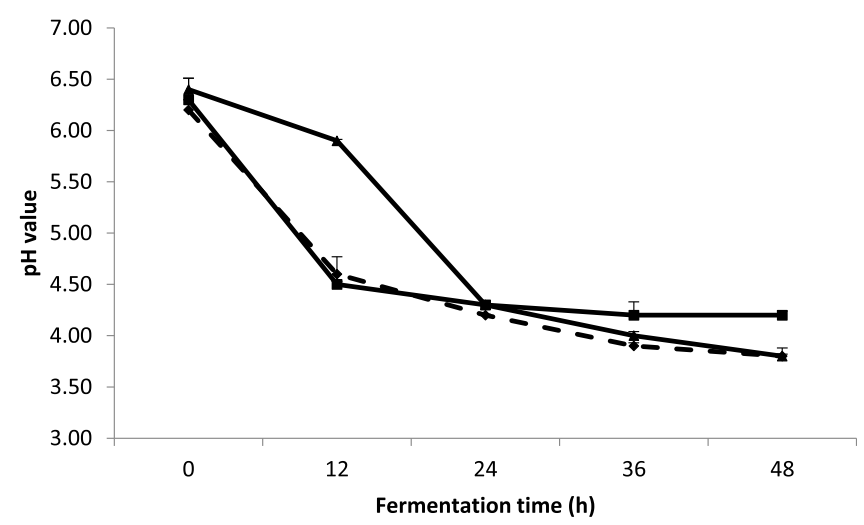

Fig. 3. Bivariate plot showing variation in $\mathrm{pH}$ with fermentation time in the produced sourdoughs. - . Finger millet-pearl millet blend, - _ _ Pearl millet-sorghum blend, $\longrightarrow$ Finger millet-sorghum blend. Plotted values are mean of triplicate readings.

8.45 $\mathrm{CFU} \mathrm{g}^{-1}$ for FP, PS and FS, respectively. A direct relationship between the growth of LAB and bacterial load could be ascertained at the commencement of the fermentation, as both followed the same pattern (Figs. 1 and 2), with the exception of PS, which was devoid of $\mathrm{LAB}$ at the beginning of the fermentation (Fig. 2). Generally, the increase in LAB count from the beginning to the end $(48 \mathrm{~h})$ of fermentation, as shown in Fig. 2, agreed with the findings of Ogunsakin, Banwo, Ogunremi, and Sanni (2015) and Wakil and Daodu (2011). The maximum LAB count recorded in PS and FS was observed at $12 \mathrm{~h}$ fermentation period. This could be due to the presence of sorghum in both samples, which provided a favourable environment and more nutrients for the growth of lactic acid bacteria. At the end of the fermentation, the FS sourdough had the highest LAB count with a value of $\log 10.52 \mathrm{CFU} \mathrm{g}^{-1}$. However, the LAB count for FP and PS sourdoughs were not significantly different $(\mathrm{P}<0.05)$ at $48 \mathrm{~h}$ fermentation. All the sourdoughs satisfied the minimum LAB count threshold of log 7.00 $\mathrm{CFU} \mathrm{g}^{-1}$ (Corsetti, 2013).

Throughout the fermentation process, no yeast was identified in any of the three sourdoughs produced. This could possibly be due to a wide range of circumstances, ranging from environmental conditions to the type of substrate used. On the contrary, Adepehin (2017, p. 237) had identified the Candida glabrata strain in finger millet sourdough. Moroni, Arendt, and Dal Bello (2011) reported that Saccharomyces cerevisiae and Candida glabrata dominated the teff sourdough while only Kazachstaniabarnetti was isolated in the buckwheat sourdough. The absence of yeast in the blend of this cereal (finger millet) with sorghum and pearl millet could be due to the synergistic effect of added cereals on the resultant substrate.

The $\mathrm{pH}$ dynamics obtained for the three sourdoughs is shown in Fig. 3. The result showed a significant $\mathrm{pH}$ decline in all the samples during the first $12 \mathrm{~h}$ of fermentation, which is an indication of an acidic fermentation. The $\mathrm{pH}$ trends in the sourdoughs were similar throughout the $48 \mathrm{~h}$ fermentation period and a consistent $\mathrm{pH}$ reduction occurred as the fermentation progressed. At the end of the fermentation, the $\mathrm{pH}$ values of the three sourdoughs fell within the range of 3.8-4.2 with FP and FS having a value of 3.8, which is an indication of the presence of more acidic by-products. A similar range of $\mathrm{pH}$ values was reported for maize sourdough (Edema \& Sanni, 2008; Muyanja \& Namugumya, 2009). The $\mathrm{pH}$ specification for a well-developed sourdough was earlier documented to be within 3.5 and 4.3 (Esteve, Barber, \& MartínezAnaya, 1994). The $\mathrm{pH}$ values of the three multigrain sourdoughs in this study fell within this range; thus, indicating that spontaneous fermentation is effective in producing sourdough from the three composite flours, which can in turn be used for making baked food.

\subsection{Microbial community of spontaneously fermented sourdoughs}

Identification of 23 distinct isolates randomly picked from three sourdoughs revealed differences in their final microbiota (Table 1). The Bacillus species was detected in three sourdoughs (Fig. 4), resulting in a total of $44.48 \%$ of the identified isolates. A single isolate (FP01, PS01 and FS02) in each of the sourdoughs was identified as Bacillus licheniformis. Based on the sequence results summarized in Table 1 , the $B a$ cillus licheniformis strain identified in the FS sourdough (Bacillus licheniformis strain DSM 13) was different from that in PS and FP (Bacillus licheniformis strain TS_16). Isolates selected from FP (3 isolates), FS (1 isolate) and PS (3 isolates) sourdoughs were identified as Bacillus subtilis, according to the 16S rRNA gene sequence (Table 1). The two identified strains, namely Bacillus subtilis and Bacillus licheniformis, were reported to exhibit antimicrobial activities against undesirable microorganisms (Compaoré et al., 2013; Liu et al., 2015); hence, its presence enhanced the safety aspect of the resultant products, especially in terms of consumption.

Approximately $52.17 \%$ of the identified isolates were LAB. This is consistent with the assertion by Gobbetti, De Angelis, Corsetti, and Di Cagno (2005), whereby lactic acid bacteria are the dominant microorganisms in sourdoughs. The rheology, flavour and nutritional properties of sourdough baked products depend on LAB activities (Gobbetti et al., 2005). Its inhibitory nature is attributed to the rapid consumption of oxygen and fermentable carbohydrate, the formation of lactate with concomitant reduction of $\mathrm{pH}$ and the acetate formed by this heterofermentative $\mathrm{LAB}$ contributes to extending the shelf-life of bread (Gänzle \& Gobbetti, 2013). The LAB harbouring in sourdoughs are Weissella confusa, Pediococcus acidilactici and Pediococcus pentosaceus.

Four isolates from the FP sourdough (FP05, FP06, FP07 and FP08) 
Table 1

Bacteria strains isolated from the three sourdoughs produced.

\begin{tabular}{|c|c|c|c|c|c|c|}
\hline Sourdough $^{\mathrm{b}}$ & Isolate code & Closest relative $^{\mathrm{a}}$ & Identity (\%) & No of strains & Accession no & Query cover \\
\hline \multirow[t]{3}{*}{ FP } & FP01 & Bacillus licheniformis strain TS_16 & 95 & 1 & KJ842639.1 & 99 \\
\hline & FP02, FP03,FP04 & Bacillus subtilis strain QD9 & 99 & 3 & EF488088.1 & 100 \\
\hline & FP05, FP06,FP07,FP08 & Pediococcus acidilactici strain KTNA3010M & 99 & 4 & KT968348.1 & 100 \\
\hline \multirow[t]{6}{*}{ PS } & PS01 & Bacillus licheniformis strain TS_16 & 99 & 1 & KJ842639.1 & 95 \\
\hline & PS02, PS03,PS04 & Bacillus subtilis strain QD9 & 100 & 3 & EF488088.1 & 99 \\
\hline & PS05 & Cronobacter sakazakii strain BDCSS014 & 100 & 1 & KU364465.1 & 99 \\
\hline & PS06, PS07 & Weissella confusa strain bcpcaqj1 & 100 & 2 & KX247764.1 & 99 \\
\hline & PS08 & Pediococcus pentosaceus strain WiKim20 & 100 & 1 & KX890131.1 & 99 \\
\hline & PS09 & Pediococcus acidilactici strain KTNA3010M & 100 & 1 & КT968348.1 & 99 \\
\hline \multirow[t]{4}{*}{ FS } & FS01 & Bacillus subtilis strain QD9 & 100 & 1 & EF488088.1 & 99 \\
\hline & FS02 & Bacillus licheniformis strain DSM 13 & 99 & 1 & KJ842639.1 & 95 \\
\hline & FS03, FS04, FS05 & Weissella confusa strain bcpcaqj1 & 100 & 3 & KX247764.1 & 99 \\
\hline & FS06 & Pediococcus pentosaceus strain WiKim 20 & 100 & 1 & KX890131.1 & 99 \\
\hline
\end{tabular}

a Species showing the closest identity to the strains isolated from the sourdoughs. The percent identity was found by performing multiple -sequence alignments in BLAST. Identification was carried out by $16 \mathrm{~S}$ rRNA gene sequencing.

b The composite flours used for producing sourdough were mixtures of two gluten free flours in a ratio of 50:50. FP is finger millet - pearl millet blend, PS is Pearl millet - sorghum blend, FS means finger millet - sorghum blend, FPS is finger millet - pearl millet blend sourdough, PSS is pearl millet and sorghum blend sourdough, FSS means finger millet- sorghum blend sourdough

\begin{tabular}{|l|l|l|l|}
\hline Presumptive micro-organisms strains & FP & PS & FS \\
\hline Bacillus subtilis strain QD9 & & & \\
\hline Pediococcus acidilactici strain KTNA3010M & & & \\
\hline Bacillus licheniformis strain TS_16 & & & \\
\hline Bacillus licheniformis strain DSM 13 & & & \\
\hline Pediococcus pentosaceus strain WiKim20 & & & \\
\hline Cronobacter sakazakii strain BDCSS014 & & & \\
\hline Weissella confusa strain bcpcaqj1 & & &
\end{tabular}

Fig. 4. Bacteria strains identified through the culture-dependent method in the two laboratory produced sourdoughs. The black and white boxes indicate the presence and absence of strains, respectively.

were identified as Pediococcus acidilactici, based on the 16S rRNA gene sequence. This strain was also identified in the PS sourdough. In contrast, there exists a dearth of Pediococcus acidilactici in the FS sourdough. At the end of the sourdough fermentation, two presumptive Pediococcus species, namely Pediococcus acidilactici and Pediococcus pentosaceus, were identified in the PS (Table 1). The presence of Pediococcus acidilactici was common in both FP and PS, while Pediococcus pentosaceus was common in PS and FS sourdoughs. Moroni et al. (2011) documented the presence of the latter species in spontaneously-fermented buckwheat and teff sourdoughs. Weissella confusa was identified in FS and PS sourdoughs (FS03, FS04, FS05, PS06 and PS07), as shown in Table 1 and Fig. 4. Some of these LAB were identified in sourdoughs produced from other gluten-free cereals (Carrizo et al., 2017; Edema \& Sanni, 2008; Ogunsakin et al., 2017).

Unlike many other sourdough microbial communities reported by previous studies, the composite sourdoughs were dominated by a range of one to three LAB, with Pediococcus spp. present in all. Pediococcus spp. is an obligate heterofermentative and facultative anaerobic LAB with complex nutritional requirements have a temperature that ranges from $25{ }^{\circ} \mathrm{C}$ to as high as $50{ }^{\circ} \mathrm{C}$, with distinct tolerance to salt and high acidity (pH of about 4.2) (Huys, Daniel, \& De Vuyst, 2013). The low pH and nutrient composition of spontaneously fermented multigrain sourdoughs are favourable for the growth of Pediococcus spp., hence, its consistent presence in all samples. The presence of the Pediococcus acidilactici strain in maize, buckwheat and teff sourdoughs have been reported (Edema \& Sanni, 2008; Moroni, Arendt, Moriissey, \& Dal Bello, 2010; Sanni, Onilude, \& Fatungase, 1998). However, aside from spontaneously fermented gluten-free sourdoughs, Pediococcus pentosaceus was not frequently isolated from conventional sourdough (Arendt \&
Moroni, 2013).

Weissella confusa, present in PS and FS sourdoughs, has been reported to share similar characteristics with Pediococcus spp., which is the obligately heterofermentative LAB and the production of dextrans or exopolysaccharides (EPS) (Kavitake, Devi, Singh, \& Shetty, 2016). Numerous studies have confirmed the presence of Weissella confusa in gluten-free sourdoughs (Moroni et al., 2011; Moroni et al., 2010; Vogelmann, Seitter, Singer, Brandt, \& Hertel, 2009). In addition, the Weisella confusa strain has been utilized as a starter culture for obushera, a traditional sorghum malt fermented beverage (Mukisa, Byaruhanga, Muyanja, Langsrud, \& Narvhus, 2016). The dextran or exopolysaccharides produced by the Weisella confusa strain has been reported to possess a molar mass of at least $106 \mathrm{~g} / \mathrm{mol}$ and typically only $2-4 \%$ of $\alpha-(1 \rightarrow 3)$-linkages (Maina, Tenkanen, Maaheim, Juvonen \&Virkki, 2008). It has numerous potential applications in the food industry (Leemhuis et al., 2013). It can be used to replace hydrocolloids for texturizing, anti-staling, or as a prebiotic additive in bread production (Tieking, Korakli, Ehrmann, Gänzle\& Vogel, 2003). In addition, it can be used as an alternative bio-thickener, which acts to viscosify, stabilize, emulsify and/or as a gelling agent in gluten-free breads (Arendt \& Moroni, 2013), as well as produces a mildly acidic bread with improved structure, volume, shelf-life and crumb softness during storage (Galle, 2013; Katina et al., 2009).

\subsection{Pasting properties}

The pasting properties of composite flour and its respective sourdough are shown in Table 2. The peak viscosity (PV) of FP, PS and FP are 79.00 RVU, 56.29 RVU and 108.50 RVU, respectively. The PV is closely associated with the degree of starch damage with high starch damage resulting in times of high viscosity (Sanni, Kosoko, Adebowale, \& Adeoye, 2004). The lower PV value of FP and PS compared to FS can be attributed to the protein and fat contents of pearl millet. Similarly, restrictions in swelling, solubilization and viscosity were dependent on the presence of lipid and other non-carbohydrates in the starch suspension (Sanni, Adebowale, Olayiwola, \& Maziya-Dixon, 2008). A comparison of the unfermented flour blends with their sourdoughs (Table 2) revealed that fermentation resulted in an increase in PV by $20.77 \%, 64.31 \%$ and $9.08 \%$ for FP, PS and FS, respectively. PV is an important characteristic of starch granules and reflects the ability of starch to swell freely before a physical breakdown. The increase in PV in the three sourdoughs indicates that spontaneous fermentation leads to a higher content of damaged starch as well as higher ability of the starches to swell freely before physical breakdown occurs. According to Ikegwu, Okechukwu, and Ekumankana (2010), a higher PV value is 
Table 2

Pasting properties of three flour blends and their sourdoughs.

\begin{tabular}{|c|c|c|c|c|c|c|c|}
\hline Sample & $\begin{array}{l}\text { Peak viscosity } \\
\text { (RVU) }\end{array}$ & $\begin{array}{l}\text { Trough viscosity } \\
\text { (RVU) }\end{array}$ & $\begin{array}{l}\text { Breakdown viscosity } \\
\text { (RVU) }\end{array}$ & $\begin{array}{l}\text { Final viscosity } \\
\text { (RVU) }\end{array}$ & $\begin{array}{l}\text { Setback viscosity } \\
(\mathrm{RVU})\end{array}$ & $\begin{array}{l}\text { Peak time } \\
(\mathrm{min})\end{array}$ & Pasting temperature $\left({ }^{\circ} \mathrm{C}\right)$ \\
\hline FP & $\begin{array}{l}79.00 \pm \\
1.93^{\mathrm{e}}\end{array}$ & $\begin{array}{l}63.88 \pm \\
1.10^{\mathrm{e}}\end{array}$ & $\begin{array}{l}15.13 \pm \\
0.81^{c}\end{array}$ & $\begin{array}{l}114.54 \pm \\
2.64^{c}\end{array}$ & $\begin{array}{l}50.67 \pm \\
1.54^{b}\end{array}$ & $\begin{array}{l}5.77 \pm \\
0.04^{d}\end{array}$ & $\begin{array}{l}82.25 \pm \\
0.92^{\mathrm{d}}\end{array}$ \\
\hline FPS & $\begin{array}{l}99.71 \pm \\
2.36^{\mathrm{d}}\end{array}$ & $\begin{array}{l}91.55 \pm \\
3.03^{\mathrm{d}}\end{array}$ & $\begin{array}{l}8.17 \pm \\
0.68^{d}\end{array}$ & $\begin{array}{l}136.58 \pm \\
5.20^{b}\end{array}$ & $\begin{array}{l}45.05 \pm \\
2.17^{c}\end{array}$ & $\begin{array}{l}7.00 \pm \\
0.00^{a}\end{array}$ & $\begin{array}{l}93.30 \pm \\
0.52^{\mathrm{a}}\end{array}$ \\
\hline PS & $\begin{array}{l}56.29 \pm \\
7.17^{f}\end{array}$ & $\begin{array}{l}55.67 \pm \\
7.03^{f}\end{array}$ & $\begin{array}{l}0.63 \pm \\
0.14^{\mathrm{f}}\end{array}$ & $\begin{array}{l}135.09 \pm \\
24.44^{\mathrm{b}}\end{array}$ & $\begin{array}{l}79.42 \pm \\
17.42^{\mathrm{a}}\end{array}$ & $\begin{array}{l}6.97 \pm \\
0.04^{\mathrm{a}}\end{array}$ & $\begin{array}{l}90.83 \pm \\
0.49 \text { bc }\end{array}$ \\
\hline PSS & $\begin{array}{l}157.71 \pm \\
1.78^{\mathrm{a}}\end{array}$ & $\begin{array}{l}131.88 \pm \\
1.50^{\mathrm{a}}\end{array}$ & $\begin{array}{l}25.84 \pm \\
3.27^{\mathrm{a}}\end{array}$ & $\begin{array}{l}166.38 \pm \\
0.53^{a}\end{array}$ & $\begin{array}{l}34.50 \pm \\
0.96^{\mathrm{c}}\end{array}$ & $\begin{array}{l}7.00 \pm \\
0.00^{a}\end{array}$ & $\begin{array}{l}91.65 \pm \\
0.40^{b}\end{array}$ \\
\hline FS & $\begin{array}{l}108.50 \pm \\
0.77^{c}\end{array}$ & $\begin{array}{l}105.29 \pm \\
1.40^{b}\end{array}$ & $\begin{array}{l}3.21 \pm \\
0.622^{\mathrm{e}}\end{array}$ & $\begin{array}{l}181.00 \pm \\
2.11^{\mathrm{a}}\end{array}$ & $\begin{array}{l}75.71 \pm \\
0.72^{a}\end{array}$ & $\begin{array}{l}6.70 \pm \\
0.19^{b}\end{array}$ & $\begin{array}{l}90.03^{ \pm} \\
0.55^{c}\end{array}$ \\
\hline FSS & $\begin{array}{l}119.33 \pm \\
2.89^{b}\end{array}$ & $\begin{array}{l}98.21 \pm \\
1.88^{c}\end{array}$ & $\begin{array}{l}21.13 \pm \\
1.01^{\mathrm{b}}\end{array}$ & $\begin{array}{l}144.92 \pm \\
4.23^{b}\end{array}$ & $\begin{array}{l}46.71 \pm \\
2.36^{b}\end{array}$ & $\begin{array}{l}6.00 \pm \\
0.15^{c}\end{array}$ & $\begin{array}{l}90.45^{ \pm} \\
0.98^{c}\end{array}$ \\
\hline
\end{tabular}

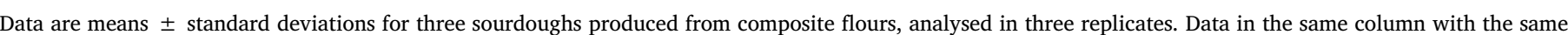
letters are not significantly different $(\mathrm{P}<0.05)$.

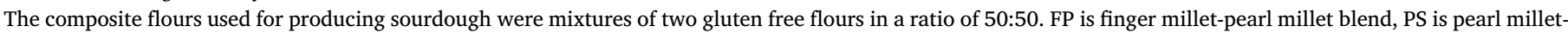

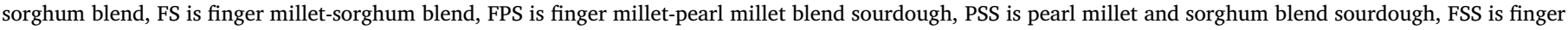
millet-sorghum blend sourdough.

indicative of the sourdough's suitability for high gel strength and elasticity requiring products, such as bread and other baked foods.

The final viscosity (RVU) of the flour blends is shown in Table 2. According to Shimelis, Meaza, and Rakshit (2006), the FV describes the quality of starch, and is indicative of its stability when cooked. It is also suggestive of the starch's capacity to form viscous paste after cooling and the lack of stability of the starch paste commonly accompanied with high breakdown value. A thorough analysis of the data in Table 2 showed that two sourdoughs (FPS and PSS) had conspicuously higher FV relative to their unfermented blends. Wokadala, Ray, and Emmambux (2012) reported that an increase in final viscosity could be due to leached amylose, which had interacted with lipids to form amylose-lipid complexes. The FV of FS decreased from 181.00 RVU to 144.92 RVU and this decline was consistent with the findings of Farasara, Hariyadi, Fardiaz, and Dewanti-Hariyadi (2014) and Oloyede, James, Ocheme, Chinma, and Akpa (2016).

Among the composite flours, the maximum trough viscosity was observed in FS, with a value of 105.29 RVU. The TV of FP and PS showed a similar trend as with the PV. Conversely, a decrease in TV by $6.73 \%$ was observed in FS. Setback viscosity (SV) measures the stability of paste during cooling and storage. Reduction in setback values indicates a low rate of starch retrogradation and syneresis (Gull, Prasad and Kumar, 2016). In all the composite flours, a significant reduction in SV occurred as a result of sourdough fermentation. This indicates a lower rate of starch retrogradation, thereby reducing the staling rate. This provides an added advantage in the form of extended shelf-life for the final baked products. Farasara et al. (2014) documented the same trend during fermentation of corn flour. The pasting properties of the three composite flours were significantly affected by the fermentation process.

\section{Conclusion}

The sourdoughs from this study were suitable for use in the production of baked food, owing to its high acidity and lactic acid bacteria content. Microbial diversity in the composite gluten-free sourdoughs were mainly LAB (Pediococcus acidilactici, Pediococcus pentosaceus, Weissella confusa) and two strains of Bacillus spp. (Bacillus licheniformis and Bacillus subtilis). These arrays of organisms found in the cereal blends have strong potential to inhibit the growth of pathogenic organisms, improve nutritional parameters and increase the shelf-life of sourdough-based baked products. The impact of sourdough fermentation on the pasting properties of flour blends is capable of lowering staling rate, thereby extending the shelf-life of the resultant food products. These outcomes establish the suitability of gluten-free composite cereals in the production of bread and other baked products.

\section{Acknowledgements}

The authors are grateful to the Editor and the three anonymous reviewers for their constructive criticisms that enhanced the quality of the manuscript. This research was made possible by the sponsorship of the Borlaug Leadership for the Enhancement of Agriculture Program (LEAP) fellowship awarded to the lead author for her Ph.D. It also enjoyed the support of UC Davis, USA and ICRISAT Nairobi, Kenya. Late Dr. (Mrs.) Edema, M.O. was instrumental in the conception of this research idea. Her contribution and mentoring is greatly acknowledged.

\section{References}

Adepehin, J. O. (2017). Sourdough fermentation of three underutilised cereals (finger millet, pearl millet, and sorghum) for bread makingAkure, Nigeria: Federal University of Technology Unpublished Ph.D. thesis submitted to the Department of Food Science and Technology.

Akinola, S. A., Badejo, A. A., Osundahunsi, O. F., \& Edema, M. O. (2017). Effect of preprocessing techniques on pearl millet flour and changes in technological properties. International Journal of Food Science and Technology, 52, 992-999.

AOAC (2005). Official methods of analysis (18th ed.). Maryland, USA: Association of Official Analytical, Chemists International.

Arendt, E. K., \& Moroni, A. (2013). Sourdough and gluten-free products. In M. Gobbetti, \& M. Gänzle (Eds.). Handbook on sourdough biotechnology (pp. 245-264). New York: Springer.

Carrizo, S. L., de Oca, C. E. M., Hébert, M. E., Saavedra, L., Vignolo, G., LeBlanc, J. G., et al. (2017). Lactic acid bacteria from andean grain amaranth: A source of vitamins and functional value enzymes. Journal of Molecular Microbiology and Biotechnology, 27(5), 289-298.

Compaoré, C. S., Nielsen, D. S., Ouoba, L. I., Berner, T. S., Nielsen, K. F., SawadogoLingani, H., et al. (2013). Co-production of surfactin and a novel bacteriocin by Bacillus subtilis subsp. subtilis H4 isolated from Bikalga, an African alkaline Hibiscus sabdariffa seed fermented condiment. International Journal of Food Microbiology, 162(3), 297-307.

Corsetti, A. (2013). Technology of sourdough fermentation and sourdough applications. In M. Gobbetti, \& M. Gänzle (Eds.). Handbook on sourdough biotechnology (pp. 85104). New York: Springer.

Corsetti, A., \& Settanni, L. (2007). Lactobacilli in sourdough fermentation. Food Research International, 40(5), 539-558.

Edema, M. O. (2010). Effect of Leuconostoc mesenteroides on the visco-elastic properties of sour maize meal. International Food Research Journal, 17, 55-61.

Edema, M. O., Emmambux, M. N., \& Taylor, J. (2013). Improvement of fonio dough properties through starch modification by sourdough fermentation. Starch/Stärke, 65(9-10), 730-737.

Edema, M. O., \& Sanni, A. I. (2008). Functional properties of selected starter cultures for sour maize bread. Food Microbiology, 25, 616-625.

Ercolini, D., Pontonio, E., De Filippis, F., Minervini, F., La Storia, A., Gobbetti, M., et al. (2013). Microbial ecology dynamics during rye and wheat sourdough preparation. Applied and Environmental Microbiology, 79(24), 7827-7836.

Esteve, C. C., Barber, C. B., \& Martínez-Anaya, M. A. (1994). Microbial sour doughs 
influence acidification properties and bread making potential of wheat dough. Journal of Food Science, 59(3), 629-633.

Farasara, R., Hariyadi, P., Fardiaz, D., \& Dewanti-Hariyadi, R. (2014). Pasting properties of white corn flours of Anoman 1 and PulutHarapan varieties as affected by fermentation process. Food and Nutrition Sciences, 5(21), 2038.

Galle, S. (2013). Sourdough: A tool to improve bread structure. In M. Gobbetti, \& M Gänzle (Eds.). Handbook on sourdough biotechnology (pp. 217-228). New York: Springer.

Gänzle, M. G., \& Gobbetti, M. (2013). Physiology and biochemistry of sourdough lactic acid bacteria. In M. Gobbetti, \& M. Gänzle (Eds.). Handbook on sourdough biotechnology (pp. 183-216). New York: Springer.

Gobbetti, M. (1998). The sourdough microflora: Interactions of lactic acid bacteria and yeasts. Trends in Food Science \& Technology, 9(7), 267-274.

Gobbetti, M., De Angelis, M., Corsetti, A., \& Di Cagno, R. (2005). Biochemistry and physiology of sourdough lactic acid bacteria. Trends in Food Science \& Technology, 16(1), 57-69.

Gull, A., Ahmad, N. G., Prasad, K., \& Kumar, P. (2016). Technological, processing and nutritional approach of finger millet (Eleusinecoracana) - a mini review. Journal of Food Processing \& Technology, 7(593), 2.

Harth, H., Van Kerrebroeck, S., \& De Vuyst, L. (2016). Community dynamics and metabolite target analysis of spontaneous, backslopped barley sourdough fermentations under laboratory and bakery conditions. International Journal of Food Microbiology, $228,22-32$.

Hu, Y., Stromeck, A., Loponen, J., Lopes-Lutz, D., Schieber, A., \& Gänzle, M. G. (2011) LCMS/MS quantification of bioactive antiotensin I-converting enzyme inhibitory peptides in rye malt sourdoughs. Journal of Agricultural and Food Chemistry, 59, 11983-11989.

Huys, G., Daniel, H. M., \& De Vuyst, L. (2013). Taxonomy and diversity of sourdough yeasts and lactic acid bacteria. In M. Gobbetti, \& M. Gänzle (Eds.). Handbook on sourdough biotechnology (pp. 105-154). New York: Springer.

Ikegwu, O. J., Okechukwu, P. E., \& Ekumankana, E. O. (2010). Physico-chemical and pasting characteristics of flour and starch from achi Brachystegiaeurycoma seed. Journal of Food Technology, 8(2), 58-66.

Katina, K., Maina, N. H., Juvonen, R., Flander, L., Johansson, L., Virkki, L., et al. (2009). In situ production and analysis of Weissella confusa dextran in wheat sourdough. Food Microbiology, 26(7), 734-743.

Kavitake, D., Devi, P. B., Singh, S. P., \& Shetty, P. H. (2016). Characterization of a novel galactan produced by Weissellaconfusa KR780676 from an acidic fermented food. International Journal of Biological Macromolecules, 86, 681-689.

Leemhuis, H., Pijning, T., Dobruchowska, J. M., van Leeuwen, S. S., Kralj, S., et al. (2013). Glucansucrases: Three-dimensional structures, reactions, mechanism, $\alpha$-glucan analysis and their implications in biotechnology and food applications. Journal of Biotechnology, 163(2), 250-272.

Liu, X., Lee, J. Y., Jeong, S. J., Cho, K. M., Kim, G. M., Shin, J. H., et al. (2015). Properties of a bacteriocin produced by Bacillus subtilis EMD4 isolated from ganjang (soy sauce). Journal of Microbiology and Biotechnology, 25(9), 1493-1501.

Maina, N. H., Tenkanen, M., Maaheimo, H., Juvonen, R., \& Virkki, L. (2008). NMR spectroscopic analysis of exopolysaccharides produced by Leuconostoc citreum and. Weissellaconfusa. Carbohydrate Research, 343(9), 1446-1455.

Moroni, A. V., Arendt, E. K., \& Dal Bello, F. (2011). Biodiversity of lactic acid bacteria and yeasts in spontaneously-fermented buckwheat and teff sourdoughs. Food Microbiology, 28(3), 497-502.

Moroni, A. V., Arendt, E. K., Moriissey, J. P., \& Dal Bello, F. (2010). Development of buck wheat and teff sourdoughs with the use of commercial starters. International Journal of Food Microbiology, 142, 142-148.

Moroni, A. V., Dal Bello, F., \& Arendt, E. K. (2009). Sourdough in gluten-free breadmaking: An ancient technology to solve a novel issue? Food Microbiology, 26(7), 676-684.

Mukisa, I. M., Byaruhanga, Y. B., Muyanja, C. M., Langsrud, T., \& Narvhus, J. A. (2016). Production of organic flavor compounds by dominant lactic acid bacteria and yeasts from Obushera, a traditional sorghum malt fermented beverage. Food Science \&
Nutrition, 5(3), http://dx.doi.org/10.1002/fsn3.450.

Muyanja, C., \& Namugumya, B. S. (2009). Traditional processing, microbiological, physiochemical and sensory characteristics of Kwete, a Ugandan fermented maize based beverage. African Journal of Food, Agriculture, Nutrition and Development, 9(4), 1046-1059.

Nazni, P., \& Shalini, S. (2010). Standardization and quality evaluation of idli prepared from pearl millet (Pennisetumglaucum). International Journal of Current Research, 5, 84-87.

Ogunsakin, O. A., Banwo, K., Ogunremi, O. R., \& Sanni, A. I. (2015). Microbiological and physicochemical properties of sourdough bread from sorghum flour. International Food Research Journal, 22(6).

Ogunsakin, A. O., Vanajakshi, V., Anu-Appaiah, K. A., Vijayendra, S. V. N., Walde, S. G., Banwo, K., et al. (2017). Evaluation of functionally important lactic acid bacteria and yeasts from Nigerian sorghum as starter cultures for gluten-free sourdough preparation. LWT-Food Science and Technology, 82, 326-334.

Oloyede, O. O., James, S., Ocheme, O. B., Chinma, C. E., \& Akpa, V. E. (2016). Effects of fermentation time on the functional and pasting properties of defatted Moringa oleifera seed flour. Food Science \& Nutrition, 4(1), 89-95.

Rollan, G., De Angelis, M., Gobbetti, M., Valdez, D., \& G. F (2005). Proteolytic activity and reduction of gliadin-like fractions by sourdough lactobacilli. Journal of Applied Microbiology, 99(6), 1495-1502.

Salovaara, H. (2004). Lactic acid bacteria in cereal-based products. In S. Salminen, A. von Wright, \& A. Ouwehand (Eds.). Lactic acid bacteria microbiological and functional aspects (pp. 431-451). (3rd ed.). New York: Marcel Dekker.

Sanni, S. A., Adebowale, A. A., Olayiwola, I. O., \& Maziya-Dixon, B. (2008). Chemica composition and pasting properties of iron fortified maize flour. Journal of Food Agriculture and Environment, 6(3\&4), 172-175.

Sanni, L. O., Kosoko, S. B., Adebowale, A. A., \& Adeoye, R. J. (2004). The influence of palm oil and chemical modification on the pasting and sensory properties of fufu flour. International Journal of Food Properties, 7(2), 229-237.

Sanni, A. I., Onilude, A. A., \& Fatungase, M. O. (1998). Production of sour maize bread using starter-cultures. World Journal of Microbiology and Biotechnology, 14(1), 101-106.

Shimelis, E. A., Meaza, M., \& Rakshit, S. K. (2006). Physico-chemical properties, pasting behavior and functional characteristics of flours and starches from improved bean (Phaseolus vulgaris L.) varieties grown in East Africa. Agricultural Engineering International: CIGR E-Journal, 8, 1-18.

Tieking, M., Korakli, M., Ehrmann, M. A., Gänzle, M. G., \& Vogel, R. F. (2003). In situ production of exopolysaccharides during sourdough fermentation by cereal and intestinal isolates of lactic acid bacteria. Applied and Environmental Microbiology, 69(2), 945-952.

Vogelmann, S., Seitter, F. H., Singer, U., Brandt, M. J., \& Hertel, C. (2009). Adaptability of lactic acid bacteria and yeasts to sourdough prepared from cereals, pseudo cereals and cassava and use of competitive strains as starters. International Journal of Food Microbiology, 130, 205-212.

Vrancken, G., Rimaux, T., Weckx, S., Leroy, F., \& De Vuyst, L. (2011). Influence of temperature and backslopping time on the microbiota of a type I propagated laboratory wheat sourdough fermentation. Applied and Environmental Microbiology, 77(8), 2716-2726.

Wakil, S. M., \& Daodu, A. A. (2011). Physiological properties of a microbial community in spontaneous fermentation of maize (Zea mays) for Ogi production. International Research Journal of Microbiology, 2(3), 109-115.

Weckx, S., Van der Meulen, R., Maes, D., Scheirlinck, I., Huys, G., Vandamme, P., et al. (2010). Lactic acid bacteria community dynamics and metabolite production of rye sourdough fermentations share characteristics of wheat and spelt sourdough fermentations. Food Microbiology, 27, 1000-1008.

Wokadala, O. C., Ray, S. S., \& Emmambux, M. N. (2012). Occurrence of amylose-lipid complexes in teff and maize starch biphasic pastes. Carbohydrate Polymers, 90(1), 616-622.

Wood, B. J. B. (1998). Microbiology of fermented foods. London United Kingdom: Blackie Academic \& Professional. 